\title{
Excessive Base Money and Global Financial Crisis in Relation to the Essence of the So-Called "Abenomics"
}

\author{
Goro Takahashi \\ International Center for Chinese Studies, Aichi University, Nagoya, Japan \\ Email: takaha@vega.aichi-u.ac.jp
}

Received August $9^{\text {th }}$, 2013; revised September $9^{\text {th }}, 2013$; accepted September $16^{\text {th }}, 2013$

\begin{abstract}
Copyright (c) 2013 Goro Takahashi. This is an open access article distributed under the Creative Commons Attribution License, which permits unrestricted use, distribution, and reproduction in any medium, provided the original work is properly cited.
\end{abstract}

\begin{abstract}
After the financial crisis of 2008, we are facing possibility of a global financial crisis further. Most of the financial crises have occurred in situations when there is so much money in the financial market, but they have not often occurred in cases when the market does not have enough money. This thought, however, is not general common sense in the financial academic field. Based on general understanding, the cause of financial crisis is the lack of money with the rise of interest rates in the financial market. If the lack of money is the reason for financial crisis, then we have never met with any financial crisis, because most leading countries have much money in the financial market nowadays. According to theory of Economics, government deficit plus current account surplus means surplus of savings in the private sector of the country. Currently, most countries with big-scale economy have big deficits in their national accounts. But there is enough money in the business sector. I focus on this aspect and then analyze the base money policy of the central bank of some countries, and analyze its effect or the meaning of excessive base money in the financial market. As a general economic rule, the excess of money in a financial market causes a low interest rate. On the other hand, governments are faced with less money. If enough money in the money market flows to the treasury account, the government gets national fiscal balance. But it is not easy for most governments to create the balance. The reason behind this is the failure of a national economic and fiscal policy, including tax policy. Many countries and communities are facing problems with the flow of money from the private sector to the government. This problem is one of the biggest international issues which should be solved immediately (Taylor, 2009). Of course, we cannot neglect the fact that there are countries having little money even their private sector like Greece, Italy, Spain, and so on. Economic growth is the only measure to solve the financial problem in these countries. I do not consider these countries in this paper. The financial markets that I focus on in this paper are the US, the EURO Area, China and Japan. Many experts and economic politician worldwide consider "Abenomics" noteworthy. It aims at increasing base money in the financial market of Japan. The biggest purpose of this policy is for breaking away from deflation. Japanese Prime Minister, Abe, also expects devaluation of the Yen, and increase in Japanese export. Later in this paper, we will see that the amount of Japanese base money had been decreased by the Central Bank of Japan before the global financial crisis of 2007. The hypothesis is that the cause of a financial crisis in recent years is in the excessive financial resources in a financial market. This paper attempts to elucidate the relation between the trend of global base money and the financial crisis.
\end{abstract}

Keywords: Financial Crisis; Abenomics; Excessive Money; Base Money; Money Stock

\section{Introduction}

After the financial crisis of 2008, we are facing possibility of a global financial crisis further. Most of the financial crises have occurred in situations when there is so much money in the financial market, but they have not often occurred in cases when the market has not enough money. This thought, however, is not general common sense in the financial academic field. Based on general understanding, the cause of financial crisis is the lack of money with the rise of interest rates in the financial market.

A finance crisis happens for various reasons. This paper observes so far the increase in a great quantity of base moneys seldom studied by the researcher. In four countries taken up in this paper, the base money amounts to $1 / 8$ - 1/3 to GDP. According to experiential data, although there are some differences in each country, it in ordinary times shows that it is 1/18 $1 / 10$.

I focus on this aspect and then analyze the base money policy of the central bank of some countries, and analyze its effect or the meaning of excessive base money in the financial market.

As a general economic rule, the excess of money in a financial market causes a low interest rate. On the other hand, governments are faced with less money. This problem is one of the biggest international issues which should be solved immediately (Taylor, 2009).

Many experts and economic politician worldwide consider "Abenomics" noteworthy. It aims at increasing base money in 
the financial market of Japan. Japanese Prime minister Abe also expects devaluation of the Yen, and increase in Japanese export. Later in this paper, we will see that the amount of Japanese base money had been decreased by the Central Bank of Japan before the global financial crisis of 2007.

This paper proved in consideration of the finance crisis in 2007 to 2008, a great quantity of increase in base money was deeply connected with the finance crisis. In order to avoid a finance crisis beforehand, it is necessary to research about a reasonable quantity of base money.

\section{Financial Crisis}

Recently, the world economy has been rocked by crises. Crises are categorized into many types: economic crisis, financial crisis, monetary crisis, stock crisis, foreign currency crisis, business crisis and so on. Economic crisis embraces financial crisis, monetary crisis and other crises. The definition of financial crisis is not so rigid. It is defined generally as the situation in which the value of financial institutions or assets drops rapidly. A financial crisis is often associated with a panic or a run on the banks, in which investors sell off assets or withdraw money from savings accounts with the expectation that the value of those assets will drop if they remain at a financial institution. If a financial situation like this continues, it will cause an economic crisis (Christianoa et al., 2004; Saunders, A. et al., 2010).

Financial crisis is currently the most serious problem in the world with regard to the economy (Jean-Philippe et al., 2000). The so called Pound crisis of 1992, Dollar crises in the 70's and 80 's, also financial crises in the 60's, 70's and 80's provoked by the Dollar crisis, "Black Monday" in 1987, the bursting of the bubble economy of Japan in the 90's, Asian financial crisis in 1997, US sub-prime financial Crisis in 2007, "Lehman Shock" in 2008 and the financial crisis of European countries are crises which seem to continue up to the present. This paper focuses on a particular financial crisis among various kinds of economic crises.

According to theory of Economics, government deficit plus current account surplus means surplus of savings in the private sector of the country. Currently, most countries with big-scale economy have big deficits in their national accounts. But there is enough money in the business sector. If the lack of money is the reason for financial crisis, then we have never met with any financial crisis, because most leading countries have much money in the financial market in nowadays. If enough money in the money market flows to the treasury account, the government gets national fiscal balance. But it is not easy for most governments to create the balance. Many countries and communities are facing problems with the flow of money from the private sector to the government.

\section{Cause of Financial Crisis}

\section{Minsky's Theory}

Hyman P. Minsky's hypothesis explains the reason behind a financial crisis.

"The first theorem of the financial instability hypothesis is that the economy has financing regimes and financing regimes in which it is the second theorem of the financial instability is that over periods of prolonged prosperity, the economy transits from financial relations that make for a stable system to financial relations that make for an unstable system" (Minsky, 1992).
Minsky's theories emphasize the macroeconomic dangers of speculative bubbles in asset prices which were not incorporated into the central bank policy. However, in the wake of the financial crises of 2007-2010, there was an increased interest in the policy implications of his theories. Some central bankers had begun to support Minsky's theories since that time.

"Suffice it to say that, with the financial world in turmoil, Minsky's work has become required reading. It is getting the recognition it richly deserves. The dramatic events of the past year and a half are a classic case of the kind of systemic breakdown that he-and relatively few others-envisioned" (Yellen, 2009).

Minsky postulates that a key factor to provoke a crisis is the accumulation of debt by the non-government sector. He said that three types of borrowers contribute to the accumulation of insolvent debt: 1) "hedge borrowers"; 2) "speculative borrowers”; and 3) "Ponzi borrowers”. Ponzi means one kind of pyramid selling.

According to Minsky, the financial crises are provoked by highly developed capitalism of after World War II. Moreover, there are five stages of a credit cycle in highly developed economies. He also says that there is an essential instability in a market economy, which means that financial instability is necessary. He describes the instability stages as follows:

1) When an economic condition is good, investors take risk.

2) Risk will continue to increase.

3) When taking the risk exceeds a certain level, it becomes impossible to obtain the benefits associated to the risks.

4) A risk expands with some economic shocks.

5) The panicked investors sell off their assets.

6) Assets price will slump.

7) Investors fall into a negative net worth which goes to bankruptcy.

8) The banks lend to investors who go bankrupt.

9) The central bank relieves banks ("Minsky Momentum").

10) Return to stage a) (Minsky, 1992).

He, however, did explain this claim; he was not able to prove his great hypothesis. The reason is not so complicated. Minsky did not find out the fact that financial crisis is provoked by the flood of money. Most financial crises do not occur in the stage where there is shortage of money. It is not only Minsky who made a mistake but also most financial researchers.

One typical researcher who made similar mistake was Professor Milton Friedman. During the 1960s, he promoted an alternative macroeconomic policy known as “monetarism”. He argued that the Phillips curve was not stable and predicted what would come to be known as stagflation. Though opposed to the existence of the Federal Reserve, Friedman argued that, given that it does exist, a steady, small expansion of the money supply was the only wise policy (Brian, 1995).

Many researchers have criticized Minsky's assertion in part. They say that the current financial market turmoil has been ignited by the collapse of the sub-prime mortgage market. And they believe it has been brought by the ideas of Hyman Minsky. Many commentators view that Minsky's framework of thinking accurately anticipated the current financial crisis. The heart of Minsky's framework is that capitalism is inherently un-stable and has self-destructive tendencies. An important mechanism for this destructive tendency is the accumulation of debt. Contrary to Minsky, an analysis shows that the existence of the central bank makes the capitalism unstable. This is the only one factor which is responsible for the current financial instability 
(Shostak, 2007).

I agree with some parts of the criticism, "the heart of Minsky's framework is that capitalism is inherently unstable and has self-destructive tendencies". To add another criticism, I believe that Minsky's assertion has not been verified using appropriate data. Nevertheless, his assertion has been supported by many researchers (Wolfson, 2002; Wray, 2009). P. Krugman, who was critical of his view, also has a posture in evaluating Minsky's theory (Krugman, 2012). I agree with most of his ideas.

The contribution of Minsky's assertion is that it has overcoming the theory of circulation of the financial crises, and has have cleared the circular movement of business fluctuation.

Every economist knows that depression is provoked as a result of business fluctuation. But most economists think that a financial depression, for example the financial depression of 1927, was provoked as the result of business cycle depression.

Most economists agree with the idea that a financial crisis has the ability to resolve the crisis by itself. I, however, disagree to that. They assert that financial depression takes place as the result of business circulation. Minsky rejected this claim. To understand why, we must consider the origin of his thought. I believe it originated from the criticism against an economic theory which Keynesian and Monetarist share.

Minsky points out that Neoclassical Synthesis is a result of a Keynesian and Monetarist fusion. In the process of this fusion, the revolutionary discernment about the function of capitalism and the theory of Keynes were lost. By Neoclassical Synthesis, for example, Keynesian theories about the characteristic of capitalist and banking system were disregarded.

He argues that these portions which are the base of the theories which produce economic instability were disregarded by Neoclassical Synthesis. And this instability is a factor reflecting the essential attribute of a capitalistic economy which increased in importance in the middle of 1960s (Minsky, 1986). Because of these arguments, many scholars agree with Minsky's theories (Wray, 2011).

\section{Other Opinions}

One of the theories supposes that the deregulation of financial services can cause a crisis (Cornetta et al., 2011). Here is a typical opinion of a well-known economist. "Fundamentally I see the crisis as the result of flawed regulation and perverse incentives in financial markets. Regulators brought into the arguments of the regulated that financial institutions could safely operate with a thinner capital cushion" (Eichengreen, 2010).

This researcher also thinks that the globalization of financial field leads the financial market to crisis. "What about globalization, which is what I was in fact asked to talk about? There are two connections. The oblique connection is between globalization and the competitive pressure that encouraged excessive risk taking. Financial institutions stretched for risk and gambled for survival as their profit margins were squeezed by growing competition" (Eichengreen, 2010).

In addition to deregulation, there is also a view that focuses on the collapse of mortgage derivatives. In this case, the financial crisis in the United States has been in mind. "Its causes include: major changes in regulation, lax regulatory oversight, a relaxation of normal standards of prudent lending and a period of abnormally low interest rates. The default on a significant fraction of subprime mortgages produced spillover effects around the world via the securitized mortgage derivatives into which these mortgages were bundled to the balance sheets of investment banks, hedge funds and conduits (which are bankowned but off their balance sheets) which intermediate between mortgage and other asset backed commercial paper and longterm securities. The uncertainty about the value of the securities collateralized by these mortgages spread uncertainty about the soundness of loans for leveraged buyouts" (Bordo, 2008).

There is another opinion. "The subprime mortgage crisis that started in 2007 was characterized by an unusually large fraction of subprime mortgages originated in 2006 and 2007 becoming delinquent or in foreclosure only months later" (Demyanyk \& Hemert, 2009).

\section{Money Has Become Globally Superfluous}

All the assertions above explain that the reason of financial crisis is indirect. On the contrary, my opinion as to why financial crisis happens is more direct: the reason is the global increase in the amount of base money. This paper, however, does not adopt the stance of Monetarism. On the other hand, this paper points out that control of money supply is very important. The policy of money supply is that an operation on interest rate and quantitative management of money in a financial market. Monetarists believe that the purpose of money control is the same as controlling inflation and adjusting social demands of goods and services. But by controlling money supply, we have noticed that it is impossible to control the market economy satisfactorily.

The only function of money control is to adjust the quantity of money in the market. What they think is that financial depression happens due to the lack or shortage of money in the financial market. Their policy depends strongly on an interestrate policy. But we know that the adequacy of money in the market is decided by all fields of economic activities, not only financial activities. And we know that a recession would happen even in a situation where there is flood of money in the financial market. It has been shown that financial crisis is not provoked by the shortage of money, but rather it is provoked by the excess of money in the global and domestic financial markets.

In this paper the relation of the flood of money and financial crisis is presented below.

On a worldwide scale, the base money is continuing to increase. Although the increase in base money is a result of the growth of the economy, it is the actual condition in which it exceeds the scale which the economy needs. We can know from Figures 1-4 for the base money of standard. The base money of standard should be more than 8 - 10 regarding the index of "GDP/base money" in the case of 4 major countries. But since 2008, the index of most the countries became less than 8 times. This means that many countries fell into the state of excess base money.

This is because the monetary financial policy has centered on a money-supply control and an interest-rate policies. These two policies aim at controlling inflation and deflation. However, the monetary financial policy did not always function ideally. The two monetary financial policies making money in the money market are effective, but controlling the base money which already appeared in the market after printing is difficult.

In this way, the increase in the amount of base money was enhanced, and it means that the control of a monetary financial policy began to be ineffective. Furthermore, this shows the 


\section{G. TAKAHASHI}

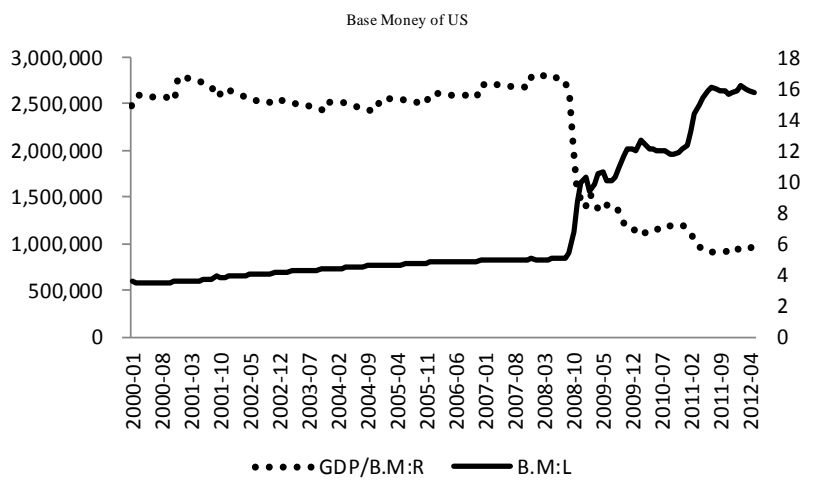

Figure 1.

Change of Base Money, GDP/Base Money: USA. Source: IMF, FRB.

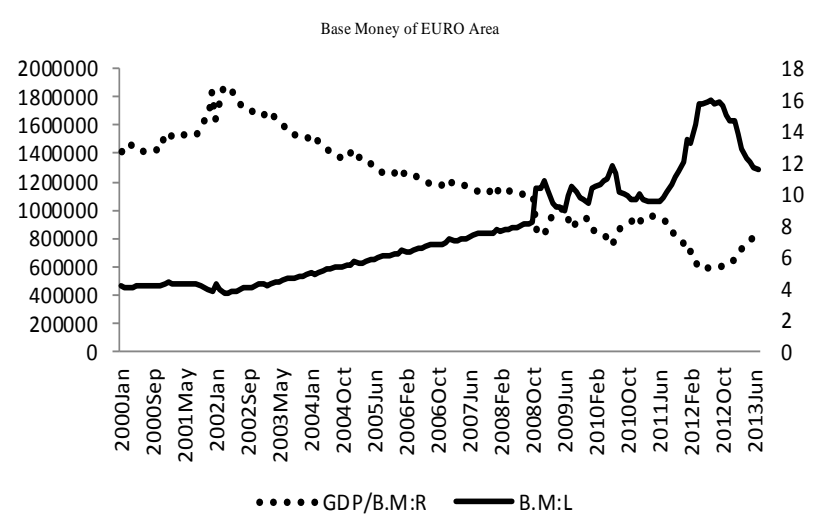

Figure 2.

Change of Base Money, GDP/Base Money: Euro Area. Source: IMF, Central Bank of EU.

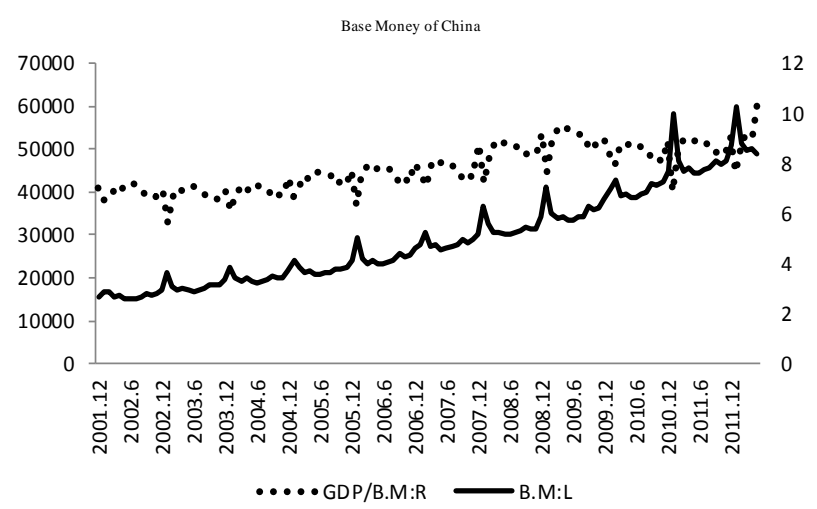

Figure 3.

Change of Base Money, GDP/Base Money: China. Source: IMF, People's Bank of China.

relevance of base money and money supply (money stock) faded gradually. The reason is the increase in cashless payment dealings and the degree of required cash contracted. This means the money supply cannot reflect the actual condition of a financial transaction. Only the base money can serve as backing for these dealings.

Figure 5 shows transition of private savings rate to GDP of major nations in 2000 onwards. Even the US with the lowest savings ratio maintains $15 \%$, and Japan and Germany show the highest level exceeding $25 \%$. Although the height of a private savings rate becomes a factor which affects governmental financial circumstances, there is also a merit that government bonds can offer with a low interest rate. But when this happens, interest rates fall in the private-financing market. In every country, the savings ratio fell greatly in 2008 because of the "Riemann shock". The rise began again after that. The fundamental reason is linked to the quantity of excess base money in the financial market.

Figure 6 shows transition of the long-term interest rate of major economies. The long interest rate of most countries was lower up to the time of "Riemann shock". However, the interest rate of Spain and Italy jumped up greatly after Riemann shock. The superfluous money of the private sector in this two coun-

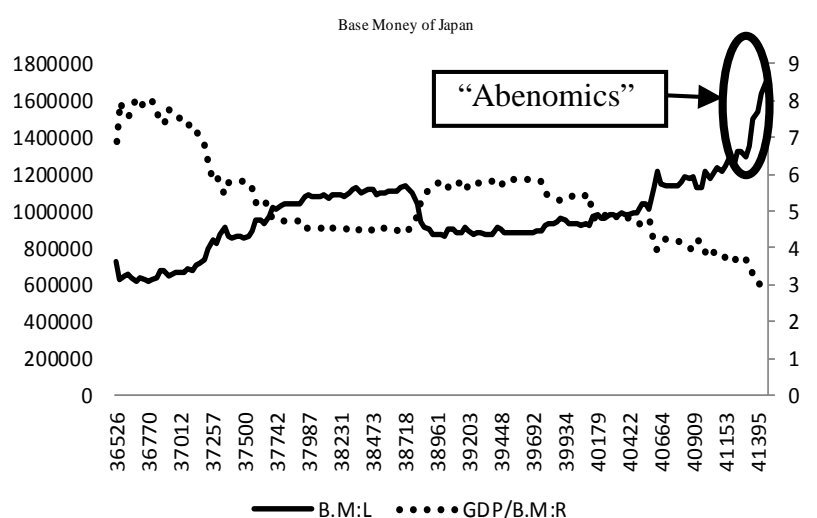

Figure 4.

Change of Base Money, GDP/Base Money: Japan. Source: IMF, Central Bank of Japan.

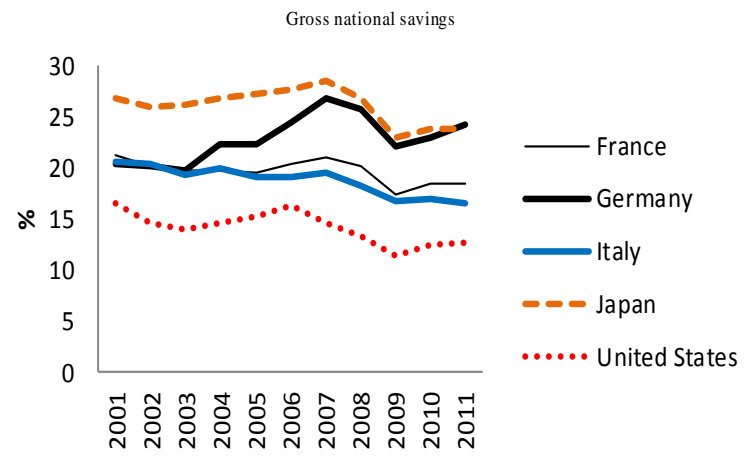

Figure 5.

Gross national savings (\%). Source: IMF.

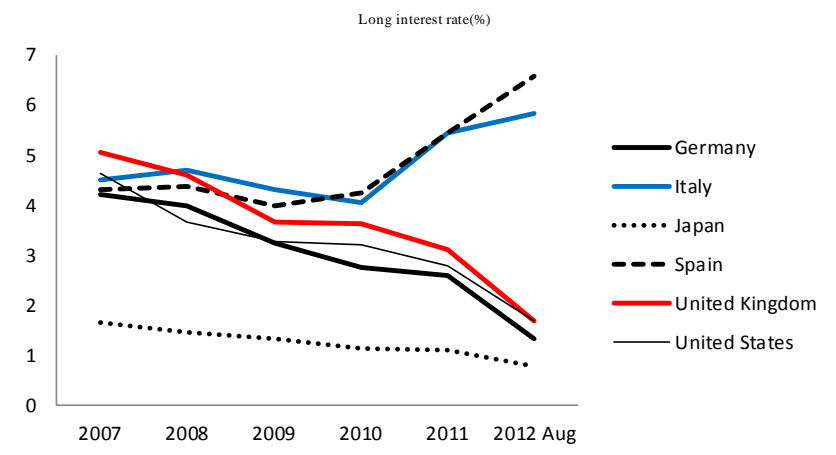

Figure 6.

Change of long interest rate (\%). Source: World Bank. 
tries disappeared, and so was the money from the Government authorities. Except for these two countries, a long-term interest rate should continue to fall. It is possible to say that this is because the quantity of base money is so much more the quantity which the market requires.

Figure 7 shows transition of real interest rate. The trend of the real interest rate differs from the case of a savings ratio and a long-term interest rate. In every country, the real interest rate is falling. In the case of China and Italy, the range of fluctuation is larger. The real interest rate of China fell sharply in 1994. This reason is because the RMB was devaluated to $\$ 1 \fallingdotseq$ RMB 8 from $\$ 1 \fallingdotseq$ RMB 5. The devaluation of the Lira of Italy and Peseta of Spain was performed at this time. The real interest rate of the Lira increased in 1992 because it seemed that the Lira left the Exchange Rate Mechanism (ERM) and the breakaway from the Europe monetary crisis was completed. Except for these exceptions, the real interest rate of world is in a downward trend, which was about $3 \%$ to $5 \%$ in general by 2010. The downward trend of a real interest rate means that a superfluous state of money exists globally.

\section{Excess of Base Money and Financial Crisis}

Figures 1-4 show that the amount of base money of the US, the EURO Area, China and Japan is increasing.

The base money of the US (Figure 1) increased steadily by 2008, and then increased rapidly. The increase was extreme; the quantity in 2012 increased 2.5 times that in 2008. The base money of the EURO Area (Figure 2) has shown a bigger increase than the US till 2008. However, the increase was lessened after 2008. Compared with 2008, it became 1.8 times that in 2012.

The base money of China (Figure 3) has tendencies to increase, and has clear fixed periodicity. It increases suddenly in January and February every year, decreases after that, and is stabilized for several months. The increasing trend of its base money is clear too. The increase in the base money of China in 2008 was slightly large.

However, usual periodicity has changed and the increase in base money became small.

The movement of the increase in base money of Japan (Figure 4) is quite typical. It increased from 2000 till the beginning of 2006, and reduced quickly in June 2006 onwards. Then, a stable increase was seen followed by a great increase in 2011 onwards.

Earlier in the paper, it was said that the so called Abenomics

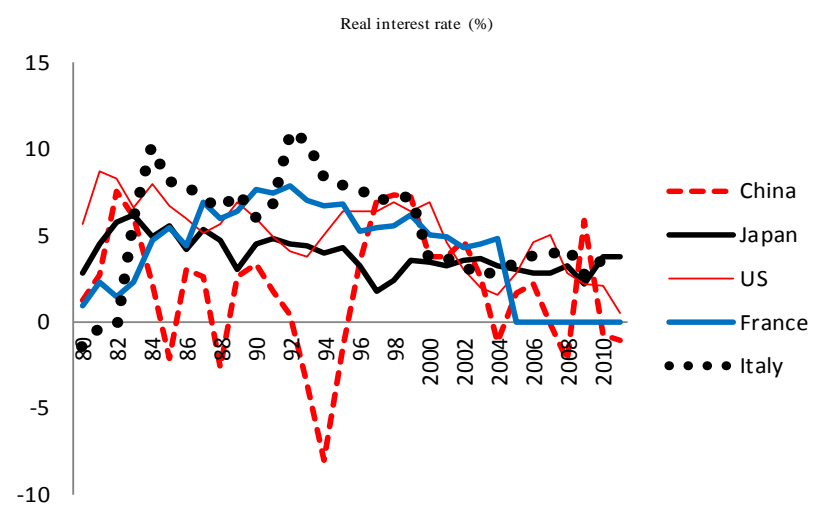

Figure 7.

Change of Real interest rate (\%). Source: World Bank. has been noteworthy to many experts and economic politicians worldwide. This policy aims at increasing the base money in the financial market of Japan, and its biggest purpose is to help the country break away from deflation. One interesting event that happened was the amount of the Japanese base money had been decreased by Central Bank of Japan before the global financial crisis of 2007.

When Japan was in the economic recession, two monetary tightening ideologists took office as the president of the Central Bank of Japan.

They are Mr. Toshihiko Fukui and Mr. Masaaki Shirakawa. These two presidents of the Central Bank ran a tight monetary policy. As a result, the amount of Japanese base money decreased for many years. It is, however, important to note that at that time the Central Bank had to run the loose monetary policy.

The central banks of many countries ran the loose monetary policy, and increased their base money. The new Japanese prime minister noticed that and would like Japan to also increase its base money. My evaluation of "Abenomics" is described next.

If devaluation of the yen proceeds, commodity and service prices will increase. But the income of the people and demand will not increase. Therefore, the economy will likely not improve. Rather, in Japan, this policy is supposed to increase the risk of financial crisis.

There are two main policies to avoid the impending crisis. The corporate tax rate of companies is as high as $35.64 \%$; it is necessary to lower it to $20 \%$. Moreover, reducing the income tax of the young generation is required. If we run this policy, corporate management will improve and business investment will recover. Consequently, domestic demand will increase without "Abenomics".

By the way, the large financial crises of the 2000s are the financial crises in 2007, 2008, and the subsequent Europe debt crisis (Reinhart et al., 2008). The reaction of the base money of each country to these financial crises was not the same. First, the change in the amount of base money in the US and the EURO Area was mostly similar to what happened in the financial crisis in 2008. That is, the base money increased greatly. However, China and Japan were peculiar. That is, there was no big change in the movement of their base money. Why does such a difference arise?

1) The financial crises in the US and the EURO Area were so serious that the base money was wiped away. However, the cause of the financial crisis was not the absolute shortage of money, but the misdistribution of money.

2) In China and Japan, the financing surplus of the private sector was large, which stopped the aggravation of the financial crisis.

If so, then when base money continues to increase more than the amount needed in the market, why does a financial crisis happen? It happens because the rate of interest tends to fall. This is because fund managers make riskier investment, and the probability of risk goes up abruptly. As a consequence, speculative transactions are generalized in global range.

Money supply multiplies base money by the monetary velocity of circulation, and is adjusted automatically by the velocity of circulation of the money which the state of economic conditions determines. The quantity of the base money in a financial market is adjusted by the central bank and interest rate in the market raised in order to absorb base money. The operation which must lower the interest rate is required. It cannot be in- 
dependent of the influence of the financial market. That is, once base money comes out to the financial market, it has the fate which can never be erased. Unlike money supply, the substantial reconciliation is impossible or very impossible for a while. If base money increases, it cannot be denied that the possibility of a financial crisis increases.

The financial crisis and the Europe debt crisis in 2008 are the occurrences that show the possibility. Figure 8 shows that the financial crisis which occurred was the result of the continuous increase in base money which raised the bad loan ratio of the bank rapidly and seriously influenced the management of banks. Figure 9 shows that Ted Spread went up rapidly. The TED spread is the difference between the interest rates of interbank loans and short-term U.S. Treasury Bond ("T-bills"). TED is an abbreviation of T-Bill and Eurodollar, the ticker symbol for the Eurodollar future contract (Chatrath et al., 1999).

\section{Consumption of GDP before Its Realization}

Excess of base money leads to one more problem. The capital development in a capitalist economy is accompanied by the exchange of present money for future money (Allen et al., 2010). Figure 10 shows that if the quantity of actual base money

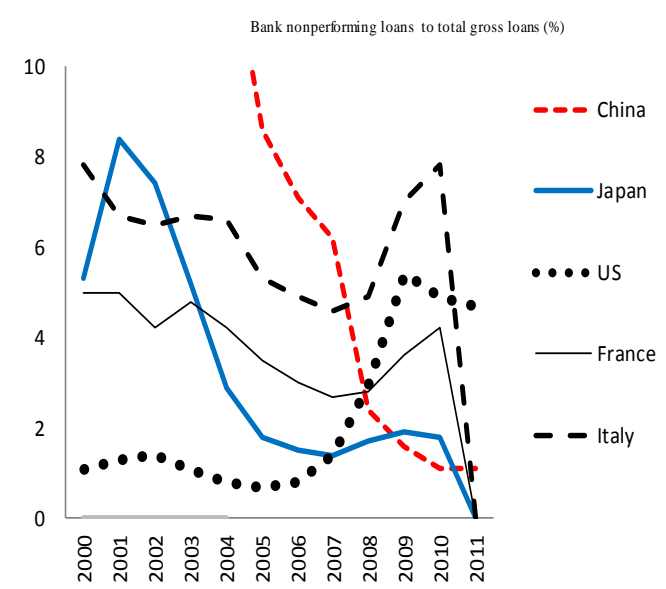

Figure 8.

Bank nonperforming loans to total gross loans (\%). Source: World Bank.

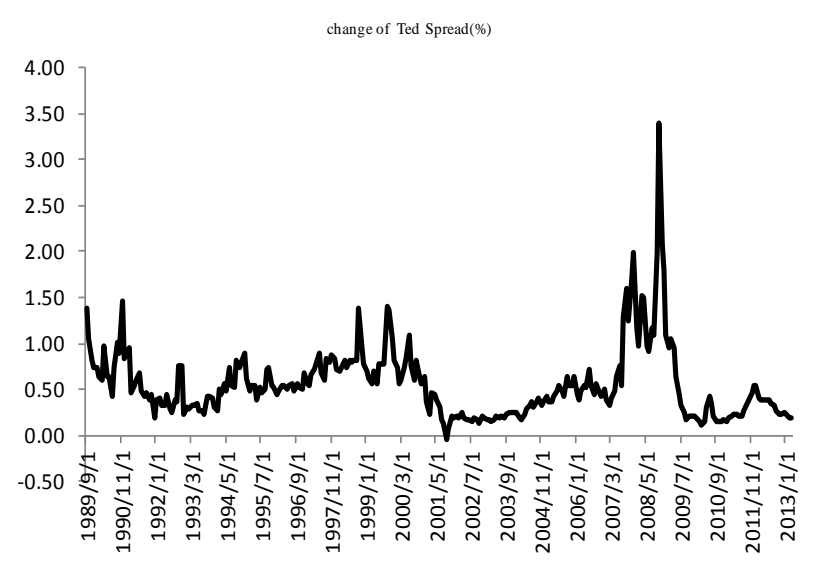

Figure 9.

Change of Ted Spread for 20 years. Source:

http://www.fedprimerate.com/libor/libor_rate_history.htm

http://research.stlouisfed.org/fred2/series/addata

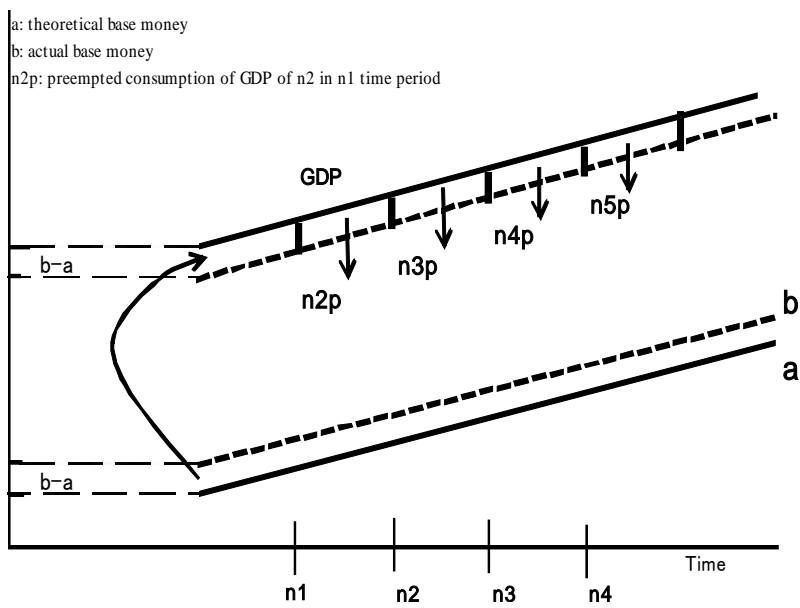

Figure 10.

Image of preempted consumption of GDP of future in current year.

which exceeds the quantity of theoretical base money, GDP of $\mathrm{n} 2$ period is consumed in advance in $\mathrm{n} 1$ period. The quantity of theoretical base money is recognized at least 8 - 10 regarding the index of "GDP/base money". The GDP quantity consumed in advance depends on the spread between the quantity of theoretical base money and the quantity of actual base money.

When the quantity of base money exceeds the proper amount, since prior consumption of GDP takes place, it is necessary to double the amount of GDP produced in the following year. When a required quantity of GDP cannot be secured, inflation may happen. On the other hand, if GDP runs short, a depression of business will come and a financial risk will increase further. A financial crisis happens based on such circumstances.

Therefore, the present big global political project is how to adjust superfluous base money to a proper quantity level. The ost important is to make international standards in managing base money.

\section{Conclusion}

In the modern global financial world the uncontrolled action of increasing base money is universal. The so called Abenomics which Japanese Prime Minister Abe is saying is one of the typical examples. The policy which increases "money stock" by increasing "base money" has been adopted by many countries so far. This policy is universal as a financial policy in main economies.

The purpose of this policy is to try to overcome the limit of interest rate control policy. Furthermore, the base money policy is becoming a very important method to avoid intervening directly in foreign exchange market. As a result, every country became interested in base money issue as an important policy.

As I have mentioned above, base money of abnormal quantity has increased in main countries. Because of this, we may face a very dangerous and serious financial crisis.

Therefore, the most important subject in the current world economy is how to have a suitable quantity of base money in every country and in the world.

\section{REFERENCES}

Taylor, J. B. (2009). The financial crisis and the policy responses: An empirical analysis of what went wrong. Working Paper 14631. Na- 


\section{G. TAKAHASHI}

tional Bureau of Economic Research, 1050.

http://www.nber.org/papers/w14631

http://dx.doi.org/10.3386/w14631

Christianoa, L. J. Gustc, C., \& Roldosd, J. (2004). Monetary policy in a financial crisis. Journal of Economic Theory, 119, 64-103.

Saunders, A., \& Allen. L. (2010). Credit risk management in and out of the financial crisis. Hoboken, NJ: John Wiley \& Sons, Inc.

Jean-Philippe, B., \& Marc, P. (2000). Theory of financial risks: From statistical physics to risk management (2nd ed.). Cambridge: Cambridge University Press.

Minsky, H. P. (1992). The financial instability hypothesis. The Jerome Levy Economics Institute of Bard College, Working Paper, No.74.

Yellen, J. L. (2009). A Minsky meltdown. Presentation to the 18th Annual Hyman P. Minsky Conference on the State of the US and World Economies- "Meeting the challenges of the financial crisis". New York: The Levy Economics Institute of Bard College.

Brian, D. (1995). Best of both worlds.

http://reason.com/archives/1995/06/01/best-of-both-worlds

Shostak, F. (2007).The Hyman Minsky theory does not explain the current financial crisis.

http://www.24hgold.com/english/contributor.aspx?contributor=Frank +shostak

Wray, L. R. (2009). Money manager capitalism and the global financial crisis. The Levy Economics Institute of Bard College, Working Paper, No. 578.

Wray, L. R. (2011). Minsky crisis. The Levy Economics Institute of Bard College, Working Paper, No. 659.

Wolfson, M. H. (2002). Minsky's theory of financial crisis in a global context. Journal of Economic Issues, 36, 393.

Krugman, P. (2012). Minsky and Methodology (Wonkish). The New York Times.

http://krugman.blogs.nytimes.com/2012/03/27/minksy-and-methodol ogy-wonkish/?_r=0

Minsky, H. P. (1986). Stabilizing an unstable economy. New Haven, CT: Yale University Press.

Cornetta, M. M., McNuttb, J. J., Strahanc, P. E., \& Tehraniand, H. (2011). Liquidity risk management and credit supply in the financial crisis. Journal of Financial Economics, 101, 297-312.

http://dx.doi.org/10.1016/j.jfineco.2011.03.001

Eichengreen, B. (2010). Globalization and the crisis. CESIFO Forum.

Bordo, M. D. (2008). An historical perspective on the crisis of 2007 2008. NBER Working Paper Series, Working Paper, 14569. http://dx.doi.org/10.3386/w14569

Demyanyk, Y., \& Van Hemert, O. (2009). Understanding the subprime mortgage crisis.

http://www.fdic.gov/bank/analytical/cfr/2008/mar/CFR_SS_2008_D emyanykHemert.pdf

Reinhart, C. M., \& Rogoff, K. S. (2008). Is the 2007 US subprime financial crisis so different? An international historical comparison. National Bureau of Economic Research, Working Paper, No. 13761. http://www.nber.org/papers/w13761

Chatrath, A., Chaudhry, M., \& David, R. C. (1999). Price discovery in strategically linked markets: The TED spread and its constituents. The Journal of Derivatives, 6, 77-87. http://dx.doi.org/10.3905/jod.1999.319131 